\section{Time trends (1992-2005) in undernutrition and obesity among children under five years of age in Alagoas State, Brazil}

\author{
Tendência temporal (1992-2005) da desnutrição \\ e da obesidade em menores de cinco anos no \\ Estado de Alagoas, Brasil
}

Tendencia temporal (1992-2005) de la desnutrición y de la obesidad en menores de cinco años en el estado de Alagoas, Brasil
Haroldo da Silva Ferreira 1,2 Juraci Almeida Cesar 2 Monica Lopes de Assunção 1 Bernardo Lessa Horta 2

\footnotetext{
${ }^{1}$ Faculdade de Nutrição, Universidade Federal de Alagoas, Maceió, Brasil. 2 Programa de Pós-graduação em Epidemiologia, Universidade Federal de Pelotas, Pelotas, Brasil.

Correspondence H. S. Ferreira Faculdade de Nutrição, Universidade Federal de Alagoas.

BR 104, Km 14, Maceió, AL 57072-970, Brasil. haroldo.ufal@gmail.com
}

\begin{abstract}
The aim of this study was to describe time trends in stunting and obesity in children under five years of age in Alagoas State, Brazil. Two surveys were conducted with representative samples, the first in $1992(n=1,228)$ and the second in 2005 ( $n=1,384)$. Stunting was defined as heightfor-age $<-2$ standard deviations and obesity as weight-for-height $>2$ standard deviations. Prevalence of stunting decreased from $22.5 \%$ to $11.4 \%$ ( $P R=0.50 ; 95 \% C I: 0.42 ; 0.60)$, while obesity increased from $6.7 \%$ to $9.3 \%$ ( $P R=1.36$; 95\%CI: 1.04; 1.77). During the same period there was a decrease $(p \leq 0.05)$ in the proportions of the following variables: rural residence, households without running water, households with more than four members, mothers with more than two children, low birth weight, and mother's lack of access to prenatal care. Adjustment for these variables significantly reduced the magnitude of associations, and the 95\% confidence included 1.0, suggesting that changes in the prevalence of stunting and obesity were mediated by these characteristics. During the period, there was a striking reduction in the prevalence of stunting and an increase in the frequency of obesity.
\end{abstract}

Protein-Energy Malnutrition; Nutrition Surveys; Preschool Child

\section{Resumo}

Objetivou-se descrever a tendência temporal do déficit estatural e da obesidade em menores de 5 anos de Alagoas, Brasil. Dois inquéritos com amostras representativas foram realizados em 1992 ( $n=1.228)$ e $2005(n=1.384)$, respectivamente. Déficit estatural foi definido pela altural idade $<-2$ desvios-padrão e obesidade por peso/ altura $>2$ desvios-padrão. A prevalência de déficit estatural mudou de 22,5\% para $11,4 \%(R P=$ 0,50; IC95\%: 0,42; 0,60), enquanto a de obesidade passou de $6,7 \%$ para $9,3 \%(R P=1,36$; IC95\%: $1,04 ; 1,77)$. No mesmo período houve redução ( $p$ $\leq 0,05)$ nas proporções das seguintes variáveis: moradores na zona rural, famílias sem acesso à água encanada, domicílios com mais de quatro pessoas, mães com mais de dois filhos, baixo peso ao nascer e mães sem acesso ao pré-natal. $O$ ajuste para essas variáveis reduziu significantemente a magnitude das associações e os IC95\% englobaram a unidade, sugerindo que as mudanças nas prevalências de desnutrição e obesidade foram mediadas por essas características. No período avaliado houve drástica redução na prevalência de déficit estatural e incremento na frequência de obesidade.

Desnutrição Proteico-Calórica; Inquéritos $\mathrm{Nu}$ tricionais; Pré-Escolar 


\section{Introduction}

Beginning with the National Survey on Family Expenses (ENDEF) in 1974, periodic surveys have been conducted in Brazil, allowing identification of the prevalence, regional distribution, and time trends in the most relevant nutritional problems in the country as a whole and in the major geographic regions. The results of these studies indicate that the Brazilian population is undergoing a nutritional transition, characterized by a reduction in the prevalence of undernutrition and a slow increase in obesity 1 . In children under five years of age, prevalence of undernutrition (stunting) decreased from $37.1 \%$ in $1974-1975$ to $7.1 \%$ in 2006-2007 2. Meanwhile, the prevalence of obesity in children in this age bracket (previously considered a negligible problem) reached virtually the same level as stunting $(7.3 \%$ versus $7.1 \%$, respectively) 3 .

These surveys were planned to obtain indicators for the Brazil as a whole and its major geographic regions, but do not allow disaggregating the data according to States of the country ${ }^{4}$. Considering that historically the prevalence of undernutrition has been higher in regions with lower economic development (stunting is two to four times more common in Northeast as compared to Southeast Brazil, according to the national surveys from 2006-2007 and 1974-1975, respectively) ${ }^{2}$, it is valid to assume that such disparities also exist at the State level, given the important socioeconomic differences among the latter.

The State of Alagoas is located in the Northeast Region of Brazil. Compared to other States, it is known for having the country's most precarious social indicators 5 . In this context, due to the epidemiological, demographic, and nutritional transition, with possible changes in the population's pattern of physical activity and eating habits 6 , the possibility exists of an increase in obesity prevalence without proper control of undernutrition, thus establishing the coexistence of both conditions at the population level and characterizing the so-called double burden of nutritional problems and their respective harm to health 7.

In 1992, the United Nations Children's Fund (UNICEF) conducted a household survey that evaluated a representative sample of children less than five years of age in Alagoas 8. A new survey was conducted in 2005 , this time by researchers from the Alagoas Federal University (UFAL) 9. This work aimed to analyze the time trends in stunting and excess weight in children under five years of age in the State of Alagoas from 1992 to 2005 .

\section{Methods}

\section{Sampling plan}

\section{- 1992 survey}

In order to obtain a representative sample, the sampling process used a multiple (three-stage) design. The first stage selected the municipalities (counties) to be included in the study $(\mathrm{n}=20)$; the second selected the census tracts in each municipality $(\mathrm{n}=8)$; and the third stage selected a starting point from which 15 consecutive households were visited. Thus, 2,400 households were visited (20 municipalities x 8 tracts x 15 households). Based on data from the Brazilian Institute of Geography and Statistics (IBGE), which estimated 0.57 children under five years of age per household, by the end of the study 1,370 children in this age bracket would be identified. This sample would allow obtaining estimates of the most common health problems and the health services' coverage, with acceptable margins of error 10 : $95 \%$ significance $(1-\alpha)$ and $80 \%$ study power $(1-\beta)$.

The municipalities were selected with probability proportional to size, i.e., municipalities with larger populations had higher odds of being included in the sample when compared to smaller ones. For example, the State capital Maceió was selected six times, which meant visiting 48 census tracts there, and thus 720 households. For each municipality selected, a list of all the census tracts was obtained from the IBGE. This list was then used to systematically select the tracts to be included in the study. After selecting the census tract, its corners were numbered, always clockwise, and one corner was randomly selected as the starting point for consecutively visiting 15 households.

The survey identified 1,351 children less than five years of age in the households visited. Of this total, it was possible to obtain information on 1,228 , resulting in a loss rate of $9.1 \%$.

\section{- 2005 survey}

Calculation of the sample size considered a prevalence rate of $9.5 \%$ for stunting 11 , a $1.5 \%$ margin of sampling error, 95\% confidence interval (95\%CI), and population estimated at 308,000 children. The sample size, calculated in StatCalc from Epi Info (Centers for Disease Control and Prevention, Atlanta, USA), was 1,461 children. The sampling process was multiple (three-stage). In the first stage, 20 municipalities (counties) were selected, with probability proportional to the population (systematic sampling). In the second stage, eight 
census tracts were selected in each municipality. In the third, a starting point was selected in each tract, from which nine consecutive residences were visited that had at least one child in the target age bracket. A total of 1,461 children less than five years of age were identified in the households visited. As a result of sampling losses ( $\mathrm{n}=$ $75 ; 5.1 \%$ ) due to refusals or the child's absence from the household, the final sample consisted of 1,386 children.

Weighting for adjustment of the urbanversus-rural relationship in the samples

Since the rural census tracts tended to be smaller than the urban, the study tended to evaluate a smaller proportion of children living in the rural area as compared to estimates from the census. Thus, the study calculated weighting factors based on the proportion of inhabitants in rural versus urban areas according to data from IBGE and the respective proportions obtained in the surveys. Weighting factors were obtained by simple rule of three. In 1992, 625 children were studied in the urban area and 603 in the rural area $(n=1,228)$. For correction as a function of the values estimated by IBGE, these numbers were multiplied by 1.1370 and 0.8590 , respectively. In 2005, 990 children were studied in the urban area and 394 in the rural area $(n=1,384)$. For adjustment, these values were multiplied by 0.8755 and 1.3128 , respectively.

\section{Data collection}

The data from the two surveys were collected through home visits conducted in July and August 1992 and from November 2005 to February 2006. Pretested structured forms were used 10, which were applied to the child's mother or guardian and included demographic, socioeconomic, environmental, nutritional, and health variables.

Anthropometric data (weight and stature) were measured by properly trained and supervised interviewers. In 1992, body weight was measured with a Salter type portable scale (CMS PBW-235; CMS Weighing Equipment, London, England), accurate to $100 \mathrm{~g}$, while in 2005 a portable electronic scale was used, with a capacity of $180 \mathrm{~kg}$ and sensitivity of $100 \mathrm{~g}$ (Marte PP180®; Marte Balanças Ltda., São Paulo, Brazil). Children older than 24 months had their stature measured in the standing position with a vertical stadiometer, while in children under two years the length was measured with the child supine, using a pediatric (horizontal) stadiometer. The equipment in both surveys included a non-flexible measuring tape, accurate to $0.1 \mathrm{~cm}$.

\section{Data analysis}

The information contained in the databanks was processed with Anthro, version 2 (World Health Organization; http://www.who.int/childgrowth/ software/en/) in order to generate anthropometric indices using the variables sex, age, weight, and stature, based on World Health Organization guidelines (OMS-2006) 12. These indices were used to produce indicators for the following conditions: underweight (weight-for-age < $-2 \mathrm{z}$ ); wasting (weight-for-height $<-2 \mathrm{z}$ ); stunting (height-for-age $<-2 z$ ); and obesity (weightfor-height $>2 \mathrm{z}$ ). The results were expressed as prevalence rates (\%) according to age brackets and year of the survey. The comparison between mean z-scores and the observed height-for-age and weight-for-height indices, respectively, in 1992 and 2005 used the Student t test for independent samples.

According to the study's objectives, the dependent variables were stunting and obesity. Socioeconomic, demographic, and health factors were described according to the prevalence rates of their respective categories. For each of these, distribution of the prevalence rates for the target outcome was presented (stunting and obesity). The F statistic was used to compare these proportions in the two surveys.

The observed increases (or decreases) in the prevalence rates in the second survey were described as percentages, using the following equation: [(prevalence in 2005 - prevalence in 1992)/ prevalence in 1992] x 100 .

Analysis of trends in the target indicators used Poisson regression with robust adjustment of variance to estimate prevalence ratios (PR). Increases were defined as PR $>1$, and the values obtained in 1992 were used as the reference. Socioeconomic, demographic, and health variables that presented statistically significant variation between the two surveys $(p<0.05)$ were used for adjustment in calculating the PR for stunting and obesity in 2005.

Importantly, the adjustment did not aim to control for confounders, but to identify factors associated with the observed changes (that is, possible determinants).

Data analysis was performed with Stata 12.0 (Stata Corp., College Station, USA), using the svy command, since the data were from complex samples.

\section{Results}

A total of 1,228 children were studied in the 1992 survey ( 619 boys and 609 girls) and 1,384 in 2005 
(677 boys and 707 girls). Table 1 shows the distribution of nutritional disorders as defined by the anthropometric extremes. In the two surveys, the prevalence rates were considered low for weightfor-height and weight-for-age deficits $(1.3 \%$ and $5.6 \%$ in 1992 and $0.9 \%$ and $2.7 \%$ in 2005 , respectively). Stunting was more concentrated in the age brackets greater than 12 months in the 1992 survey, but not in the study in 2005. Although obesity prevalence was higher in the second survey, it was not more predominant in any of the specific age brackets in either of the surveys.

Table 2 shows the distribution of socioeconomic, demographic, and health characteristics in the samples and the respective prevalence rates and measures of association with stunting and obesity. From 1992 to 2005 there was a significant reduction $(\mathrm{p} \leq 0.05)$ in the proportion of: residents in the rural area, families without access to running water, households with more than four residents, mothers with more than two children, children with low birth weight $(<$ $2,500 \mathrm{~g}$ ), and mothers without access to prenatal care. This same period also witnessed an increase in the proportion of adolescent mothers.

The following variables showed statistically significant associations with increased obesity: living in the urban area, mother not having more than two children, and birth weight $\geq 4,000 \mathrm{~g}$ Meanwhile, higher prevalence rates of stunting were associated with living in the rural area, households without running water, mothers with more than two children, birth weight less than $2,500 \mathrm{~g}$, mothers without access to prenatal care, and maternal age greater than 40 years.

Table 3 shows the time trends in prevalence of stunting and obesity. Prevalence of stunting showed a $49.3 \%$ decrease, while obesity increased by $38.8 \%$. However, as shown in Table 2 , for both situations, adjustment of the prevalence ratios for the predictors associated with these outcomes, respectively $(p \leq 0.05)$, reduced the magnitude of associations and the confidence intervals included 1.0, showing that the observed changes in prevalence of stunting and obesity in the second survey were heavily influenced by alterations in the behavior of these predictors.

Changes in prevalence rates of the dependent variables during the period were reflected in the $\mathrm{z}$-score values for the anthropometric indices used to comprise the respective indicators: the mean z-score for the weight-for-height index increased from $0.45 \pm 1.05$ in 1992 to $0.63 \pm 1.12$ in 2005 ( $\mathrm{p}<0.001$ ), while the mean $\mathrm{z}$-score for the height-for-age index changed from $-0.92 \pm 1.56$ to $-0.49 \pm 1.29$ during the same period $(\mathrm{p}<0.0001)$.

\section{Discussion}

In Latin America, especially in Brazil, there has been a rapid demographic, epidemiological, and nutritional transition. As a consequence, the population has experienced a sharp change in the distribution of individual nutritional status, characterized by a decrease in the frequency of undernutrition and an increase in obesity 13,14. This observation is corroborated by the current study's findings, whereby from 1992 and 2005 the prevalence of stunting in children less than five years of age decreased by $49.3 \%$, while the prevalence of obesity increased by $38.8 \%$.

Notwithstanding the socioeconomic and structural differences within and between Brazil's major geographic regions 15 , this process has occurred nationwide, and the results of various population-based surveys conducted on comparable dates corroborate the current study's findings $16,17,18,19,20$

In Pernambuco State, from 199116 to 2006 17, there was a $61 \%$ reduction in the prevalence of stunting, from $24.6 \%$ to $9.6 \%$. Meanwhile, in the second survey obesity prevalence reached $8.1 \% 18$, close to the level observed for stunting thus displaying opposite trends in undernutrition and obesity, characteristic of the third stage of the nutritional transition, with the appearance of excess weight on a population scale 21 .

In a municipality in South Brazil (Pelotas, Rio Grande do Sul State), Barros et al. 19 compared the trends in stunting and obesity in one-year-old children, based on three birth cohorts launched in 1982, 1993, and 2004. They observed a $27.7 \%$ decline in the prevalence of stunting (from 8.3\% to $6 \%$ ). Meanwhile, the number of obese children increased by $26.2 \%$ (from $6.5 \%$ to $8.2 \%$ ).

Two nationwide studies were conducted on dates close to the surveys in Alagoas, namely the National Demographic and Health Surveys (PNDS) of 1996 and 2006 20. During this period undernutrition decreased from $13.4 \%$ to $6.7 \%$. However, contrary to the other studies cited above, the prevalence of obesity remained stable between the two surveys $(7.2 \%$ and $7.3 \%$, respectively).

Concerning the upward trend in prevalence of overweight as reported here, Uauy \& Kain 22 call attention to the fact that programs for the prevention of undernutrition require periodic evaluation, including a clear definition of their beneficiaries due to the possible effects on obesity, to the extent that such programs can lead to a positive energy balance in individuals not subject to hunger and undernutrition. Thus, given the current epidemiological reality, characterized by the coexistence of undernutrition and obesity, 
Table 1

Prevalence (\%) of nutritional disorders defined by anthropometric extremes in children less than five years of age in Alagoas State, Brazil, by age bracket, according to two surveys (1992 and 2005).

\begin{tabular}{|c|c|c|c|c|c|c|c|c|c|c|}
\hline \multirow{2}{*}{$\begin{array}{l}\text { Age bracket } \\
\text { (months) }\end{array}$} & \multicolumn{2}{|c|}{ Sample } & \multicolumn{2}{|c|}{ Underweight * } & \multicolumn{2}{|c|}{ Wasting ** } & \multicolumn{2}{|c|}{ 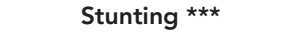 } & \multicolumn{2}{|c|}{ Obesity \# } \\
\hline & 1992 & 2005 & 1992 & 2005 & 1992 & 2005 & 1992 & 2005 & 1992 & 2005 \\
\hline$\leq 6.0$ & 159 & 204 & 4.4 & 3.3 & 3.8 & 1.6 & 5.8 & 8.6 & 8.1 & 9.1 \\
\hline $6.1-12$ & 137 & 175 & 7.7 & 4.3 & 2.7 & 0.8 & 9.8 & 11.0 & 7.3 & 13.0 \\
\hline $12.1-24$ & 212 & 306 & 8.9 & 3.0 & 1.8 & 1.1 & 24.4 & 13.1 & 8.2 & 11.1 \\
\hline $24.1-36$ & 243 & 301 & 5.7 & 1.7 & 0.0 & 0.0 & 30.7 & 15.2 & 8.0 & 7.5 \\
\hline $36.1-48$ & 250 & 239 & 2.4 & 2.7 & 0.0 & 0.7 & 26.4 & 8.8 & 5.8 & 9.0 \\
\hline $48.1-60$ & 227 & 159 & 5.3 & 1.9 & 1.0 & 0.0 & 27.8 & 8.9 & 4.4 & 5.8 \\
\hline Total $(95 \% \mathrm{Cl})$ & 1,228 & 1,384 & $\begin{array}{c}5.6 \\
(4.4 ; 7.0)\end{array}$ & $\begin{array}{c}2.8 \\
(2.0 ; 3.8)\end{array}$ & $\begin{array}{c}1.3 \\
(0.8 ; 2.1)\end{array}$ & $\begin{array}{c}0.7 \\
(0.4 ; 1.4)\end{array}$ & $\begin{array}{c}22.5 \\
(20.4 ; 24.9)\end{array}$ & $\begin{array}{c}11.4 \\
(9.8 ; 13.3)\end{array}$ & $\begin{array}{c}6.7 \\
(5.5 ; 8.4)\end{array}$ & $\begin{array}{c}9.3 \\
(7.9 ; 11.0)\end{array}$ \\
\hline
\end{tabular}

95\% Cl: 95\% confidence interval.

* Weight-for-age < -2 standard deviations (SD);

** Weight-for-height $<-2 S D$;

$\star \star \star *$ Height-for-age <-2SD;

\# Weight-for-height $>$ 2SD

Table 2

Prevalence, prevalence ratios, and $95 \%$ confidence intervals $(95 \% \mathrm{Cl})$ for obesity and stunting, according to categories of socioeconomic, demographic, and health variables in children under five in Alagoas State, Brazil.

\begin{tabular}{|c|c|c|c|c|c|c|c|c|c|c|}
\hline \multirow[t]{2}{*}{ Variable/Category } & \multirow{2}{*}{$\begin{array}{c}1992 \\
(\%)\end{array}$} & \multirow{2}{*}{$\begin{array}{c}2005 \\
(\%)\end{array}$} & \multirow{2}{*}{$\begin{array}{c}\text { Variation } \\
\text { (\%) }\end{array}$} & \multirow{2}{*}{$\begin{array}{c}\text { p-value } \\
\text { (F) }\end{array}$} & \multicolumn{2}{|c|}{ Obesity * (\%) } & \multirow[t]{2}{*}{$P R * *(95 \% \mathrm{Cl})$} & \multicolumn{2}{|c|}{ Stunting *** $(\%)$} & \multirow[t]{2}{*}{ PR $(95 \% \mathrm{Cl})$} \\
\hline & & & & & 1992 & 2005 & & 1992 & 2005 & \\
\hline \multicolumn{11}{|l|}{ Area } \\
\hline Urban & 57.9 & 62.6 & 8.1 & 0.016 & 7.4 & 10.6 & $1.44(1.03 ; 2.00) \#$ & 18.2 & 9.9 & $0.54(0.42 ; 0.70) \#$ \\
\hline Rural & 42.1 & 37.4 & -11.2 & & 6.2 & 7.1 & $1.15(0.72 ; 1.86)$ & 28.7 & 14.0 & $0.48(0.37 ; 0.64) \#$ \\
\hline \multicolumn{11}{|c|}{ Access to running water } \\
\hline Yes & 52.1 & 72.0 & 38.2 & $<0.001$ & 6.9 & 10.4 & $1.50(1.06 ; 2.14) \#$ & 15.4 & 8.3 & $0.54(0.41 ; 0.71) \#$ \\
\hline No & 47.9 & 28.0 & -41.5 & & 6.8 & 6.6 & $0.96(0.58 ; 1.58)$ & 30.6 & 19.4 & $0.63(0.49 ; 0.81) \#$ \\
\hline \multicolumn{11}{|c|}{ Household with $>4$ members } \\
\hline Yes & 71.1 & 43.3 & -39.1 & $<0.001$ & 6.5 & 10.4 & $1.60(1.13 ; 2.26) \#$ & 25.0 & 9.2 & $0.37(0.28 ; 0.48)$ \# \\
\hline No & 28.9 & 56.7 & 96.2 & & 7.4 & 8.5 & $1.15(0.74 ; 1.80)$ & 16.5 & 13.1 & $0.80(0.58 ; 1.08)$ \\
\hline \multicolumn{11}{|c|}{ Diarrhea in previous 15 days } \\
\hline Yes & 25.2 & 23.2 & -7.9 & 0.252 & 6.7 & 7.9 & $1.17(0.66 ; 2.07)$ & 23.9 & 14.4 & $0.60(0.43 ; 0.84) \#$ \\
\hline No & 74.8 & 76.8 & 2.7 & & 6.9 & 9.7 & $1.41(1.04 ; 1.91) \#$ & 22.2 & 10.5 & $0.47(0.38 ; 0.59) \#$ \\
\hline \multicolumn{11}{|c|}{ Mothers with $>2$ children } \\
\hline Yes & 59.6 & 32.2 & -46.0 & $<0.001$ & 5.8 & 6.9 & $1.19(0.71 ; 1.98)$ & 28.9 & 16.6 & $0.58(0.43 ; 0.78) \#$ \\
\hline No & 40.4 & 67.8 & 67.8 & & 8.7 & 10.6 & $1.22(0.84 ; 1.77)$ & 12.9 & 8.2 & $0.63(0.45 ; 0.89) \#$ \\
\hline \multicolumn{11}{|c|}{ Low birth weight $(<2,500 \mathrm{~g})$} \\
\hline Yes & 9.7 & 5.9 & -39.2 & 0.002 & 5.0 & 3.5 & $0.70(0.13 ; 3.79)$ & 28.3 & 20.4 & $0.72(0.41 ; 1.28)$ \\
\hline No & 90.3 & 94.1 & 4.2 & & 7.6 & 10.0 & $1.31(0.97 ; 1.79)$ & 15.1 & 10.5 & $0.70(0.55 ; 0.89) \#$ \\
\hline \multicolumn{11}{|c|}{ High birth weight $(\geq 4,000 \mathrm{~g})$} \\
\hline Yes & 14.2 & 9.9 & -30.3 & 0.003 & 9.9 & 18.5 & $1.87(0.95 ; 3.70)$ & 11.0 & 6.3 & $0.57(0.24 ; 1.34)$ \\
\hline No & 85.8 & 90.1 & 5.0 & & 6.9 & 8.6 & $1.25(0.89 ; 1.74)$ & 17.2 & 11.6 & $0.67(0.54 ; 0.85) \#$ \\
\hline
\end{tabular}




\begin{tabular}{|c|c|c|c|c|c|c|c|c|c|c|}
\hline \multirow[t]{2}{*}{ Variable/Category } & \multirow{2}{*}{$\begin{array}{c}1992 \\
(\%)\end{array}$} & \multirow{2}{*}{$\begin{array}{c}2005 \\
(\%)\end{array}$} & \multirow{2}{*}{$\begin{array}{c}\text { Variation } \\
\text { (\%) }\end{array}$} & \multirow{2}{*}{$\begin{array}{c}\text { p-value } \\
\text { (F) }\end{array}$} & \multicolumn{2}{|c|}{ Obesity * (\%) } & \multirow[t]{2}{*}{$P R * \star(95 \% \mathrm{Cl})$} & \multicolumn{2}{|c|}{ 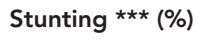 } & \multirow[t]{2}{*}{ PR (95\%Cl) } \\
\hline & & & & & 1992 & 2005 & & 1992 & 2005 & \\
\hline \multicolumn{11}{|c|}{ Number of prenatal visits } \\
\hline None & 43.6 & 24.8 & -43.1 & $<0.001$ & 7.3 & 6.9 & $0.95(0.58 ; 1.56)$ & 34.5 & 12.9 & $0.37(0.27 ; 0.51) \#$ \\
\hline $1-4$ & 21.2 & 15.6 & -26.4 & & 5.5 & 9.7 & $1.78(0.90 ; 3.52)$ & 23.5 & 16.2 & $0.68(0.46 ; 1.01)$ \\
\hline$\geq 5$ & 35.2 & 59.6 & 69.3 & & 6.4 & 10.2 & $1.60(1.03 ; 2.50)$ & 7.3 & 9.5 & $1.30(0.86 ; 1.99)$ \\
\hline \multicolumn{11}{|c|}{ Maternal age bracket (years) } \\
\hline$<19$ & 9.9 & 21.9 & 121.2 & $<0.001$ & 5.0 & 10.5 & $2.08(0.88 ; 4.94)$ & 16.1 & 12.1 & $0.75(0.45 ; 1.27)$ \\
\hline $19-40$ & 82.3 & 75.2 & -8.6 & & 7.1 & 9.5 & $1.33(0.99 ; 1.81)$ & 22.1 & 11.0 & $0.50(0.40 ; 0.62) \#$ \\
\hline$>40$ & 7.8 & 2.9 & -62.8 & & 6.4 & 0.0 & - & 31.8 & 21.7 & $0.68(0.33 ; 1.42)$ \\
\hline
\end{tabular}

F: F statistic; PR: prevalence ratio calculated by Poisson regression.

* Weight-for-height $>2 z$;

** PR was calculated using the year of the first survey (1992) as the reference;

$\star \star \star ~ H e i g h t-f o r-a g e ~<-2 z ;$

$\# p \leq 0.05$ (statistically significant difference).

Table 3

Time trends in stunting and obesity in children under five years of age in two surveys in Alagoas State, Brazil. (1992-2005).

\begin{tabular}{|c|c|c|c|c|c|c|c|c|}
\hline \multirow[t]{4}{*}{ Condition } & \multicolumn{2}{|c|}{ Prevalence } & \multirow[t]{4}{*}{ Difference } & \multirow[t]{4}{*}{ Variation (\%) } & \multirow{4}{*}{$\begin{array}{c}\text { Crude PR } \\
(95 \% \mathrm{Cl})\end{array}$} & \multirow[t]{4}{*}{ p-value } & \multirow{4}{*}{$\begin{array}{l}\text { Adjusted PR * } \\
(95 \% \mathrm{Cl})\end{array}$} & \multirow[t]{4}{*}{$\mathrm{p}$-value } \\
\hline & 1992 & 2005 & & & & & & \\
\hline & $(n=1,228)$ & $(n=1,384)$ & & & & & & \\
\hline & $\%(95 \% \mathrm{Cl})$ & $\%(95 \% \mathrm{Cl})$ & & & & & & \\
\hline \multirow[t]{2}{*}{ Stunting ** } & 22.5 & 11.4 & -11.1 & -49.3 & 0.50 & $<0.001$ & 0.93 & 0.56 \\
\hline & $(20.2 ; 24.9)$ & $(9.7 ; 13.1)$ & & & $(0.42 ; 0.60)$ & & $(0.72 ; 1.19)$ & \\
\hline \multirow[t]{2}{*}{ Obesity *** } & 6.7 & 9.3 & 2.6 & 38.8 & 1.36 & 0.025 & 1.18 & 0.29 \\
\hline & $(5.3 ; 8.2)$ & $(7.8 ; 11.0)$ & & & $(1.04 ; 1.77)$ & & $(0.86 ; 1.64)$ & \\
\hline
\end{tabular}

* For obesity, adjustment considered the following variables: area of residence (urban; rural); number of children $(\leq 2 ;>2)$, and birth weight; for stunting the control variables were area of residence (urban; rural); access to running water in household (yes; no); number of children ( $\leq 2$; $>2$ ); birth weight; access to prenatal care $(0,1$ to 4 , and 5 or more visits), and maternal age bracket $(<19,19$ to 40 , and $\geq 40$ years);

** Height-for-age < -2 standard deviations (SD);

$\star \star \star$ Weight-for-height $>$ 2SD.

it is no longer possible to establish generalized programs for the prevention and control of undernutrition.

The nutritional transition is attributed mainly to socioeconomic and demographic changes and those related to public services infrastructure 21,23. Important changes that have occurred in Alagoas can explain the findings presented here. According to Carvalho 24, Alagoas presented the second lowest human development index of all the Brazilian States. Nevertheless, during the 1990s it was also the State that achieved the greatest advances in education $(31 \%)$ and health (16\%), with a positive variation on the order of $20 \%$ in comparison to other States. Improved management of investments in the social area, especially in primary education and public health programs, were the main reasons for this growth.

The current study showed favorable trends in a series of variables associated with children's nutritional status, which contributed to the decrease in the prevalence of undernutrition, but which favored an increase in obesity prevalence. Monteiro et al. 23 analyzed the causes of the decline in stunting in Brazilian children from 1996 to 2007 and identified the following variables: increase in maternal schooling, growth in families' purchasing power, expansion of healthcare, and improved sanitation. Menezes et al. 16 analyzed 
the time trend in stunting in children under five in the State of Pernambuco based on surveys conducted in 1991, 1997, and 2006 and found a $64.6 \%$ reduction from 1991 to 2006 (from $24.6 \%$ to $8.7 \%$ ). All the determinants analyzed improved during the period analyzed; those that remained after adjustment were socioeconomic variables (per capita family income, maternal schooling, number of household members, and access to consumer goods), besides birth weight and maternal height.

Although the State of Alagoas still presents the country's most precarious social indicators, the investments made in public services infrastructure, especially in health and education, in addition to the large amount of Federal funds invested in the State through conditional income transfer programs, appear to at least partially explain the striking reduction in the prevalence of undernutrition in preschool-age children. Meanwhile, the prevalence of overweight has increased gradually, so that the two conditions now appear with virtually identical magnitude, thus emphasizing not only the importance of maintaining actions to control undernutrition, but also the need to expand measures to prevent overweight, since both represent health problems with serious repercussions in the short and long term. This is a key issue for public policymakers, indicating that access to food should be accompanied by an educational process aimed at adequately meeting nutritional needs, in addition to health promotion.

In conclusion, a nutritional transition was observed during the period studied here, consistent with the transition in Brazil as a whole, characterized by a sharp reduction in the prevalence of undernutrition and an increase in obesity.

\section{Resumen}

Se tuvo por objetivo describir la tendencia temporal del déficit de estatura y de la obesidad en menores de 5 años de Alagoas, Brasil. Dos encuestas con muestras representativas fueron realizados en $1992(n=1.228)$ y $2005(n=1.384)$. El déficit de estatura fue definido por la alturaledad < -2 desvios-padrón y obesidad por pesolaltura $>2$ desvíos-padrón. La prevalencia de déficit de estatura cambió de un 22,5\% a un 11,4\% $R P=0,50$; IC95\%: 0,42; 0,60), mientras que la de obesidad pasó de un $6,7 \%$ a un 9,3\% (RP = 1,36; IC95\%: 1,04; 1,77). En el mismo período hubo una reducción $(p \leq 0,05)$ en las proporciones de las siguientes variables: habitantes en la zona rural, familias sin acceso al agua corriente, domicilios con más de cuatro personas, madres con más de dos hijos, bajo peso al nacer y madres sin acceso al servicio prenatal. El ajuste para esas variables redujo significantemente la magnitud de las asociaciones y los IC95\% englobaron la unidad, sugiriendo que los cambios en las prevalencias de desnutrición y obesidad fueron mediados por esas características. En el período evaluado hubo una drástica reducción en la prevalencia de déficit de estatura e incremento en la frecuencia de obesidad.

Desnutrición Proteico-Calórica; Encuestas

Nutricionales; Preescolar

\section{Contributors}

H. S. Ferreira and M. L. Assunção wrote the initial version. H. S. Ferreira, B. L. Horta, and J. A. Cesar elaborated the analytical plan. All the authors participated in writing and approving the final version of the article.

\section{Acknowledgments}

The authors wish to thank UNICEF, the Alagoas State Health Secretariat, FAPEAL, and the Brazilian Ministry of Health for the research funding. 


\section{References}

1. Batista-Filho M, Assis AM, Kac G. Transição nutricional: conceito e características. In: Kac G, Sichieri R, Gigante DP, organizadores. Epidemiologia nutricional. Rio de Janeiro: Editora Fiocruz/Editora Atheneu; 2007. p. 201-12

2. Victora CG, Aquino EML, Leal MC, Monteiro CA Barros FC, Szwarcwald CL. Maternal and child health in Brazil: progress and challenges. Lancet 2011; 377:1863-76.

3. Monteiro CA, Conde WL, Konno SC, Lima ALL, Silva ACF, Benício MHD’A. Avaliação antropométrica do estado nutricional de mulheres em idade fértil e crianças menores de cinco anos. In: Ministério da Saúde; Centro Brasileiro de Análise Planejamento, organizadores. Pesquisa Nacional de Demografia e Saúde da Criança e da Mulher - PNDS 2006. Dimensões do processo reprodutivo e da saúde da criança. Brasília: Ministério da Saúde; 2009. p. 213 30. (Série G. Estatística e Informação em Saúde).

4. Viacava F. Informações em saúde: a importância dos inquéritos populacionais. Ciênc Saúde Coletiva $2002 ; 7: 607-21$.

5. Urani A. Um diagnóstico socioeconômico do Estado de Alagoas a partir de uma leitura dos dados da Pesquisa Nacional por Amostra de Domicílios do IBGE (1992-2004). Maceió: Instituto de Estudos do Trabalho e Sociedade; 2005.

6. Mendonça CP, Anjos LA. Aspectos das práticas alimentares e da atividade física como determinantes do crescimento do sobrepeso/obesidade no Brasil. Cad Saúde Pública 2004; 20:698-709.

7. Coutinho JG, Gentil PC, Toral N. A desnutrição e obesidade no Brasil: o enfrentamento com base na agenda única da nutrição. Cad Saúde Pública 2008; 24 Suppl 2:S332-40.

8. Fundo das Nações Unidas para a Infância. Crianças e adolescentes em Alagoas: saúde, educação e trabalho. Maceió: Fundo das Nações Unidas para a Infância/Governo do Estado de Alagoas; 1993.

9. Ferreira HS, Luciano SCM. Prevalência de extremos antropométricos em crianças do estado de Alagoas. Rev Saúde Pública 2010; 44:377-80.

10. Victora CG, Barros FC, Tomasi E, Ferreira FS, MacAuliffe J, Silva AC, et al. A saúde das crianças dos Estados do Ceará, Rio Grande do Norte e Sergipe, Brasil: descrição de uma metodologia para diagnósticos comunitários. Rev Saúde Pública $1991 ; 25: 218-25$

11. Ferreira HS, Assunção ML, Florêncio TMMT, Lima MAA. Estado nutricional de pré-escolares da região semi-árida do estado de Alagoas. Cadernos de Estudos Desenvolvimento Social em Debate 2006; (4):37-42.

12. World Health Organization. WHO child growth standards: length/height-for-age, weight-for-age weight-for-length, weight-for-height and body mass index-for-age: methods and development. Geneva: World Health Organization; 2006.
13. Uauy R, Albala C, Kain J. Obesity trends in Latin America: transiting from under to overweight. J Nutr 2001; 131:893S-9S.

14. Popkin BM. Contemporary nutritional transition: determinants of diet and its impact on body com position. Proc Nutr Soc 2011; 70:82-91.

15. Assis AM, Barreto ML, Santos NS, Oliveira LP, Santos SM, Pinheiro SM. Inequality, poverty, and child hood health and nutritional conditions in Northeast Brazil. Cad Saúde Pública 2007; 23:2337-50.

16. Menezes RC, Lira PI, Leal VS, Oliveira JS, Santana SC, Sequeira LA, et al. Determinantes do déficit es tatural em menores de cinco anos no Estado de Pernambuco. Rev Saúde Pública 2011; 45:1079-87.

17. Leal VS, Lira PI, Menezes RC, Oliveira JS, Sequeir LA, Andrade SL, et al. Fatores associados ao declínio do déficit estatural em crianças e adolescentes em Pernambuco. Rev Saúde Pública 2012; 46: 234-41.

18. Menezes RC, Lira PI, Oliveira JS, Leal VS, Santana SC, Andrade SL, et al. Prevalência e determinantes do excesso de peso em pré-escolares. J Pediatr (Rio J.) 2011; 87:231-7.

19. Barros AJ, Victora CG, Santos IS, Matijasevich A, Araújo CL, Barros FC. Infant malnutrition and obesity in three population-based birth cohort studies in Southern Brazil: trends and differences. Cad Saúde Pública 2008; 24 Suppl 3:S417-26.

20. Priore SE, Gontijo CA, Faria ER, Faria FR, Cecon RS, Franceschini SC. Inquéritos nacionais de antropometria e consumo alimentar. In: Taddei JA, Lang RF, Longo-Silva G, Toloni MH, organizadores. Nutrição em saúde pública. v. 1. Rio de Janeiro: Rubio; 2011. p. 99-150.

21. Batista Filho M, Rissin A. A transição nutricional no Brasil: tendências regionais e temporais. Cad Saúde Pública 2003; 19 Suppl 1:S181-91.

22. Uauy R, Kain J. The epidemiological transition: need to incorporate obesity prevention into nu trition programmes. Public Health Nutr 2002; 5:223-9.

23. Monteiro CA, Benício MHD’A, Konno SC, Silva AC, Lima AL, Conde WL. Causes for the decline in child undernutrition in Brazil, 1996-2007. Rev Saúde Pública 2009; 43:35-43.

24. Carvalho CP. Economia popular: uma via de modernização para Alagoas. 2ạ Ed. Maceió: EDUFAL; 2007

Submitted on $20 /$ Jun/2012

Final version resubmitted on $05 /$ Nov/2012 Approved 22/Nov/2012 